\title{
Re-Evaluation of the Effect of Daily and Within-Day Mixed Feeding Schedules of Varying Dietary Protein Content on the Growth Performance of Nile Tilapia Fry Using Constant Ingredient Composition
}

\author{
Ashraf Suloma1, Osama El-Husseiny', Ehab El-Haroun', Heba Salim ${ }^{1}$ and Al-Azab Tahoun ${ }^{2 *}$ \\ ${ }^{1}$ Fish Nutrition Laboratory (FNL), Animal Production Department, Faculty of Agriculture, Cairo University, Egypt, 12613, Giza, Egypt \\ ${ }^{2}$ Aquaculture Department, Fish Resources Faculty, Suez University, Egypt
}

\begin{abstract}
Feed is the main cost to aquaculture production, management practices, and feeding strategies are aimed at optimizing feed intake and efficiency. Knowledge about feeding protocols and behavior habits may be of an interest for optimization of aquaculture production, reducing aquaculture waste output and to achieve sustainability. This study investigated trends based on daily and within-day feeding schedules. Two growth trials were conducted to investigate the effect of daily and within-day mixed feeding schedules on the growth performance of Nile tilapia. Three experimental isocaloric diets of low (A; $20 \%$ ), regular feeding (RF; $30 \%)$ and high (B; $40 \%)$ protein levels were prepared. In the first trial, fish were continuously fed a normal protein diet (RF-30\%), alternate feeding of a 1-day diet $A$; followed by a 1-day diet $B(1 \mathrm{~A} / 1 \mathrm{~B})$ and alternate feeding of 2-day $\operatorname{diet} A$; followed by a 2-day diet $B(2 A / 2 B)$ and a 3-day diet $A$ followed by a 3-day diet $B(3 A / 3 B)$ were tested. In the second trial, three within-day feeding schedules were continuously examined by feeding tilapia with diet (RF), alternate feeding of $\operatorname{diet} A$ in the morning followed by $\operatorname{diet} B$ in the afternoon ( $A$ am/B pm) and alternate feeding of diet $B$ in the morning followed by diet $A$ in the afternoon (B am/A pm). In the first trial, the best specific growth rate (SGR) was observed for fry maintained on the RF diet followed by $(2 \mathrm{~A} / 2 \mathrm{~B})$. In the second trial, the mixed feeding schedule $(\mathrm{A}$ am/B pm) showed the best $S \mathrm{R}$ and feed conversion ratio (FCR) followed by a RF diet. The overall ranking of daily mixed feeding schedules was the highest for RF diet with the mixed feeding schedule of (3A/3B). In addition, within-day mixed feeding schedules showed that fish utilize high protein diet more efficiently during an afternoon phase rather than a morning phase. The results from this study show that, the within-day feeding schedule achieved better growth performance, nutrients retention and feed utilization of Nile tilapia rather than alternate feeding schedules between days for Nile tilapia.
\end{abstract}

Keywords: Feeding schedules; Dietary protein; Growth performance; Nile tilapia

\section{Introduction}

Nutrition constitutes more than $50 \%$ of the total production costs in intensive fish culture systems [1-3]. Protein represents the most expensive part of fish diets. Consequently, considerable efforts have been directed towards the evaluation of protein sources that could provide an alternative to an expensive fish meal in formulated feeds for farmed fish [4-8]. Another approach to improve feed efficiency especially protein retention and reduce feed costs is to develop suitable feeding management strategies [1,9-12]. The concept of mixed feed schedules was developed by De Silva [9]. It was primarily based on the observations of the daily variation in apparent dry matter and protein digestibility of feed in the Asian cichlid and Nile tilapia [13,14]. The above observations led De Silva [9] to hypothesize that when the fish are provided with a high protein diet throughout the rearing period it might not be able to utilize the feed effectively to the same degree, day after day. This hypothesis was tested in many cultured species including Nile tilapia [9,15-17], common carp [18-21], Catla Catla [22], Channa striata [23] and silver carp [24]. Fish exhibit a distinct diel pattern in feeding $[25,26]$. Previous studies reported that fish have different patterns in their feeding rhythms: photophase is the preferable feeding time for specific species and they called diurnal feeders such as goldfish, rainbow trout, sea bass and green black founder [27-32], while, other species consider scotophase is the preferable feeding time such as African catfish and Atlantic salmon [33,34]. However, fish farms continue to distribute feed during normal working hours, regardless of any feeding rhythm of the cultivated species. Thus, the incorrect feeding time of day could lead to low efficiency of feed utilization [35]. Earlier studies on mixed feed schedule were designed to feed the fish two diets alternatively in comparison with fish fed on one diet continuously, but no research has thus far been conducted to minimize the confounding effect of variables other than the mixed feeding schedules (e.g. ingredient quality, nutrients requirements, ingredients composition, etc.). Therefore the objectives of this study were: 1) re-evaluate the effect of mixed feeding schedules on optimized feed utilization by ensuring that the formulation, ingredients origin and chemical composition of the tested diets similar to the regular feeding (RF) diet composition, and 2) test the effects of different mixed feeding schedule within-day on growth performance and feed utilization.

\section{Materials and Methods}

\section{Fish and feeding}

Nile tilapia (Oreochromis niloticus) obtained from a local hatchery were adapted to experimental conditions for 2 weeks before the start

*Corresponding author: Al-Azab Tahoun, Aquaculture Department, Fish Resources Faculty, Suez University, Egypt, Tel: + 201006279620; Fax: +20623674264; E-mail: azab.tahoun@suezuniv.edu.eg

Received December 15, 2015; Accepted January 19, 2017; Published January 21, 2017

Citation: Suloma A, El-Husseiny O, El-Haroun E, Salim H, Tahoun A (2017) ReEvaluation of the Effect of Daily and Within-Day Mixed Feeding Schedules of Varying Dietary Protein Content on the Growth Performance of Nile Tilapia Fry Using Constant Ingredient Composition. J Aquac Res Development S2: 009. doi:10.4172/2155-9546.S2-009

Copyright: ( 2017 Suloma A, et al. This is an open-access article distributed under the terms of the Creative Commons Attribution License, which permits unrestricted use, distribution, and reproduction in any medium, provided the original author and source are credited. 
of the experiment. During that period, they were fed a high-quality commercial tilapia twice daily. Twenty fish, each weighing $(2.75$ $\pm 0.01 \mathrm{~g}$ ) on average, were randomly distributed into 18 tanks and supplied with filtered well water at a rate of approximately $3 \mathrm{l} / \mathrm{min}$. The water was continuously aerated, and the temperature was controlled thermostatically at $28^{\circ} \mathrm{C}$ to $29^{\circ} \mathrm{C}$. Each experimental diet was allocated to three tanks according to a completely randomized design. Each tank was considered an experimental unit. A pair-feeding protocol that matched protein, energy and vitamin/mineral content among all treatments was used. During the 8-week experimental period, the bulk weight of fish in each tank was recorded every 2 weeks. At the beginning of the experiment, a pooled sample of 18 fish was taken for determining chemical body composition (initial carcass sample). At the end of the experiment, five fish from each tank were sampled. Fish were killed with an excess concentration of anesthetic ( $t$-amyl alcohol) and then weighed. The fish were then pooled per tank (final carcass sample) for chemical analyses. The pooled fish samples were cooked in an autoclave, ground into homogeneous slurry in a food processor, freeze dried, and stored at $-20^{\circ} \mathrm{C}$ until analyzed.

\section{Experimental diets}

Three practical diets with different protein levels were used in both trials in order to design different feeding schedules; a low protein $\operatorname{diet}(20 \%, \mathrm{~A})$, an intermediate regular protein diet (RF; 30\% CP) and a high protein diet $(40 \% \mathrm{CP}, \mathrm{B})$. Although the intermediate protein diet $(30 \%)$ was not used in the mixed feeding schedule, this diet was used in this trial as the control to compare the effect of growth and feed utilization of the fry with the mixed feeding schedule. Diets were prepared using locally available feed ingredients. Formulation and proximate composition of the experimental diets are shown in Table 1. All the ingredients were mixed and the diets were pelleted using an electric home meat grinder. The pellets were then dried overnight under forced air at room temperature and stored at $4^{\circ} \mathrm{C}$ until used. Diets were crushed into crumble for easier acceptance by smaller fish. In mixed feed schedule treatments, fish were given the same ingredient

\begin{tabular}{|c|c|c|c|c|}
\hline Ingredient \% & $30 \%$ (RF) & $40 \%(B)$ & $20 \%(\mathrm{~A})$ & Mixed Feed schedules ${ }^{(1)}$ \\
\hline Fish meal & 20 & 33 & 8 & 20.5 \\
\hline Soybean meal & 39 & 47 & 30 & 38.5 \\
\hline Corn & 33 & 12 & 54 & 33.0 \\
\hline Oil & 6 & 6 & 6 & 6 \\
\hline $\begin{array}{l}\text { Vitamin- mineral } \\
\text { premix }^{(2)}\end{array}$ & 2 & 2 & 2 & 2 \\
\hline \multicolumn{5}{|c|}{ Crude protein contribution from each ingredient } \\
\hline Fish meal & 11.0 & 18.2 & 4.40 & 11.3 \\
\hline Soybean meal & 16.38 & 19.7 & 12.60 & 16.2 \\
\hline Corn & 2.64 & 1.0 & 4.3 & 2.6 \\
\hline \multicolumn{5}{|c|}{ Chemical composition determined } \\
\hline Dry Matter & 94.2 & 94.6 & 94.0 & 94.3 \\
\hline Lipid & 11.7 & 15.1 & 9.5 & 12.3 \\
\hline Crude protein & 29.4 & 38.5 & 22.6 & 30.6 \\
\hline Ash & 10.9 & 16.5 & 5.9 & 11.2 \\
\hline $\begin{array}{l}\text { Gross Energy } \\
\text { (Kcal/100g) }\end{array}$ & 476.8 & 483.9 & 476.7 & 480.4 \\
\hline \multicolumn{5}{|c|}{$\begin{array}{l}{ }^{1} \text { The average formulation and composition of the feed offered to the fish in the } \\
\text { mixed schedules, i.e., the average of the } 40 \% \text { and } 20 \% \text { feeds. } \\
\text { }{ }^{2} \text { Vitamins and minerals mixture each } 3 \mathrm{~kg} \text { of mixture contains: } 10000000 \mathrm{I} . \mathrm{U} \text {. } \\
\text { vit A, } 2500000 \mathrm{IU} \text { vit D3, } 10,000 \mathrm{mg} \text { vit. E, } 1000 \mathrm{mg} \text { vit. K, } 1000 \mathrm{mg} \text { vit. B1, } \\
5000 \text { vit. mg.B2, } 1500 \mathrm{mg} \text { vit.B6, } 10 \mathrm{mg} \text { vit B12, } 30,000 \mathrm{mg} \text { Niacin, } 10000 \mathrm{mg} \\
\text { Pantothenic acid, } 1000 \mathrm{mg} \text { Folic acid, } 50 \mathrm{mg} \text { Biotin, } 300 \mathrm{mg} \text { lodine, } 30,000 \\
\text { mg Iron, } 60000 \mathrm{mg} \text { Manganese, } 4000 \mathrm{mg} \text { Copper, } 100 \mathrm{mg} \text {. Cobalt, } 100 \mathrm{mg} \\
\text { Selenium, } 50,000 \mathrm{mg} \text { Zinc, } 3000 \mathrm{~g} \text { Calcium Carbonate }\end{array}$} \\
\hline
\end{tabular}

Table 1: Formulation and chemical composition of the experimental diets. and nutrient composition, to minimize the confounding effect of variables other than mixed feeding schedules factor which was not considered in previews studies (Table 1). In the first trial, four different feeding schedules were implemented: continuous regular feeding on protein diets (RF, $30 \%$ ), that represent the control diet for both trials, alternate feeding of 1-day diet A followed by a 1-day diet $C(1 \mathrm{~A} / 1 \mathrm{~B})$, alternate feeding of 2-day diet A; followed by 2 -day diet $C(2 \mathrm{~A} / 2 \mathrm{~B})$ and alternate feeding of 3-day diet $\mathrm{A}$; followed by 3-day diet $\mathrm{C}(3 \mathrm{~A} / 3 \mathrm{~B})$, where A refers to the low protein diet $(20 \% \mathrm{CP})$ and $\mathrm{B}$ refers to the high protein diet $(40 \% \mathrm{CP})$, and the numerical value refers to the number of days that a particular diet was offered to fish. In the second trial, the fish daily rations were divided into two equal meals: morning (am) and afternoon (pm) to examine the effect of three daily protein schedules on tilapia performance. The three diets $(20 \%, 30 \%$ and $40 \%$ $\mathrm{CP})$ were employed to achieve different protein schedules as follows: (30\% am-30\% pm), (20\% am-40\% pm) and (40\% am-20\% pm). The daily feed ration was $5 \%$ based on live body weight. The quantity of food was adjusted every 15 days when the weight measurement was taken. Daily feed rations were divided into two equal amounts given at 10:00 and $1700 \mathrm{~h}$ to all tanks. At the end of the experiment, all fish were individually weighed, euthanized and preserved at $-80^{\circ} \mathrm{C}$ in a freezer until subsequent chemical analyses.

\section{Chemical analysis}

Diet and carcass samples were analyzed for dry matter (DM) and ash contents according to AOAC [36] methods, crude protein (Nx6.25) by Kjeldahl method, fat (solvent extraction with petroleum ether, BP 40-60 Co 129 for $10-12 \mathrm{~h}$ ), ash (oven incineration at $550^{\circ} \mathrm{C}$ ), while nitrogen free extract was calculated by difference. Gross energy was calculated using conversion factors of 9.5, 5.6 and $4.2 \mathrm{Kcal} \mathrm{g}^{-1}$ for fat, protein, and carbohydrate, respectively [37].

\section{Calculations}

Growth and feed utilization parameters were determined according to the following formulas:

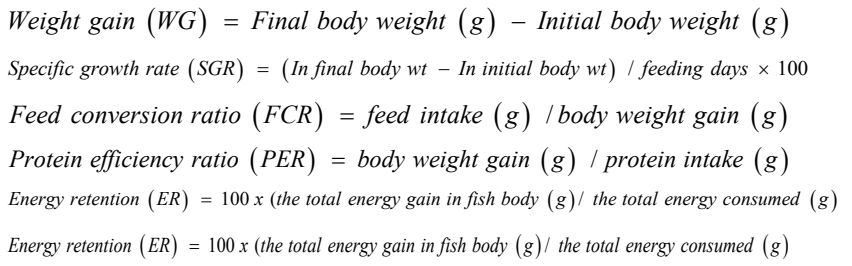

\section{Statistical analyses}

Data were analyzed as a randomized complete block design (RCBD) using the GLM procedure of SAS [38] (SAS Inst., Inc., Cary, NC, USA). Tukey's multiple range tests was used to compare differences among individual means. Treatment effects were considered significant at $(\mathrm{P}$ $\leq 0.05)$.

\section{Results}

In the first trial, the growth responses and feed utilization are presented in Table 2. Fish maintained on feeding schedules with constant protein content $(\mathrm{RF})$ and feeding schedule $2 \mathrm{~A} / 2 \mathrm{~B}$ followed by the daily feeding schedule $3 \mathrm{~A} / 3 \mathrm{~B}$ showed a significantly better growth performance and nutrient retention. The lowest growth performance and feed efficiency response were observed for $1 \mathrm{~A} / 1 \mathrm{~B}$. The best significant FCR for tilapia fry was recorded for RF and the worst FCR was observed for 1A/1B. Energy retention showed a significant difference between the treatments groups Table 2. Meanwhile, an 
Citation: Suloma A, El-Husseiny O, El-Haroun E, Salim H, Tahoun A (2017) Re-Evaluation of the Effect of Daily and Within-Day Mixed Feeding Schedules of Varying Dietary Protein Content on the Growth Performance of Nile Tilapia Fry Using Constant Ingredient Composition. J Aquac Res Development S2: 009. doi:10.4172/2155-9546.S2-009

Page 3 of 5

\begin{tabular}{|c|c|c|c|c|}
\hline Treatments & Control (RF) & 1A/1B & 2A/2B & 3A/3B \\
\hline Initial weight (g) & $2.7 \pm 0.01$ & $2.7 \pm 0.0$ & $2.7 \pm 0.0$ & $2.7 \pm 0.0$ \\
\hline Final weight (g) & $9.6 \pm 0.4^{a}$ & $8.2 \pm 0.2^{b}$ & $9.5 \pm 0.2^{\mathrm{a}}$ & $9.2 \pm 0.3^{\mathrm{ab}}$ \\
\hline Gain, wet gain (g/fish) & $6.9 \pm 0.4^{a}$ & $5.5 \pm 0.2^{b}$ & $6.8 \pm 0.1^{a}$ & $6.5 \pm 0.3^{\mathrm{ab}}$ \\
\hline Feed dry weight (g) & $13.3 \pm 0.0$ & $13.6 \pm 0.1$ & $13.5 \pm 0.3$ & $13.5 \pm 0.2$ \\
\hline Feed conversion ratio & $1.9 \pm 0.1^{a}$ & $2.5 \pm 0.1^{b}$ & $2.0 \pm 0.0^{b}$ & $2.1 \pm 0.1^{b}$ \\
\hline Specific growth rate & $2.3 \pm 0.1^{a}$ & $2.0 \pm 0.1^{b}$ & $2.2 \pm 0.0^{\mathrm{a}}$ & $2.2 \pm 0.1^{\mathrm{ab}}$ \\
\hline Protein efficiency ratio & $1.8 \pm 0.1^{a}$ & $1.3 \pm 0.1^{b}$ & $1.6 \pm 0.0^{\mathrm{a}}$ & $1.6 \pm 1.0^{\mathrm{ab}}$ \\
\hline Nitrogen retention & $24.5 \pm 1.9^{a}$ & $17.6 \pm 1.7^{\mathrm{b}}$ & $23.7 \pm 0.4^{a}$ & $20.8 \pm 1.5^{\mathrm{ab}}$ \\
\hline Energy retention & $17.0 \pm 1.6^{\mathrm{a}}$ & $12.5 \pm 0.9^{b}$ & $16.5 \pm 1.1^{\mathrm{a}}$ & $17.6 \pm 1.5^{\mathrm{a}}$ \\
\hline Survival rate $(\%)$ & 98.5 & 99.0 & 99.2 & 100.0 \\
\hline
\end{tabular}

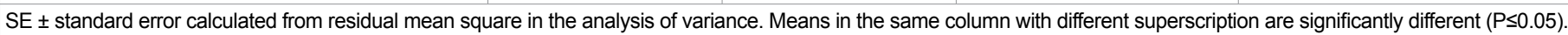

Table 2: Growth, feed conversion ratio, nitrogen retention and energy retention of Nile tilapia fed different daily mixed feeding schedules for 56 days.

\begin{tabular}{|c|c|c|c|}
\hline Treatments & Control (RF) & 1A/1B & 2A/2B \\
\hline Moisture $\%$ & $76.7 \pm 0.7$ & $77.3 \pm 0.3$ & $77.0 \pm 0.6$ \\
\hline Crud protein\% & $12.3 \pm 0.3$ & $11.7 \pm 0.5$ & $12.8 \pm 0.2$ \\
\hline lipid \% & $7.2 \pm 0.4^{\mathrm{ab}}$ & $6.7 \pm 0.0^{\mathrm{b}}$ & $7.1 \pm 0.9^{\mathrm{ab}}$ \\
\hline Ash \% & $3.6 \pm 0.4$ & $3.5 \pm 0.2$ & $3.6 \pm 0.3$ \\
\hline Gross energy (Kcal/100g) & $459.9 \pm 18.1$ & $456.855 \pm 20.1$ & 46.18 \\
\hline
\end{tabular}

$\mathrm{SE} \pm$ standard errors calculated from residual mean square in the analysis of variance .Means in the same column with different superscription are significantly different $(P \leq 0.05)$.

Table 3: Chemical body composition of the whole carcass of Nile tilapia fed different daily mixed feeding schedules for 56 days.

\begin{tabular}{|c|c|c|c|}
\hline Treatments & RF am/RF pm & $\mathbf{A} \mathbf{~ a m} / \mathbf{B ~ p m}$ & $\mathbf{B}$ am/A pm \\
\hline Initial weight $(\mathrm{g})$ & $2.7 \pm 0.0$ & $2.7 \pm 0.00$ & $2.7 \pm 0.01$ \\
\hline Final weight $(\mathrm{g})$ & $9.8 \pm 0.4^{\mathrm{a}}$ & $10.4 \pm 0.14^{\mathrm{a}}$ & $9.0 \pm 0.17^{\mathrm{b}}$ \\
\hline Gain, wet gain (g/fish) & $6.9 \pm 0.4^{\mathrm{a}}$ & $7.7 \pm 0.15^{\mathrm{a}}$ & $6.3 \pm 0.16^{\mathrm{b}}$ \\
\hline Feed dry weight $(\mathrm{g})$ & $13.3 \pm 0.0$ & $13.8 \pm 0.09$ & $13.8 \pm 0.12$ \\
\hline Feed conversion ratio & $1.9 \pm 0.1^{\mathrm{ab}}$ & $1.8 \pm 0.03^{\mathrm{a}}$ & $2.2 \pm 0.3^{\mathrm{c}}$ \\
\hline Specific growth rate & $2.3 \pm 0.1^{\mathrm{b}}$ & $2.4 \pm 0.03^{\mathrm{ab}}$ & $2.1 \pm 0.03^{\mathrm{c}}$ \\
\hline Protein efficiency ratio & $1.8 \pm 0.1^{\mathrm{a}}$ & $1.8 \pm 0.03^{\mathrm{a}}$ & $1.5 \pm 0.03^{\mathrm{b}}$ \\
\hline Nitrogen retention & $24.5 \pm 1.9^{\mathrm{a}}$ & $24.2 \pm 0.30^{\mathrm{a}}$ & $19.9 \pm 0.58^{\mathrm{b}}$ \\
\hline Energy retention & $17.0 \pm 1.6^{\mathrm{ab}}$ & $18.1 \pm 0.21^{\mathrm{a}}$ & $15.5 \pm 1.16^{\mathrm{b}}$ \\
\hline Survival rate $(\%)$ & 100 & 100 & 100 \\
\hline
\end{tabular}

$\mathrm{SE} \pm$ standard error calculated from residual mean square in the analysis of variance. Means in the same column with different superscription are significantly different $(\mathrm{P} \leq 0.05)$

Table 4: Growth, feed conversion ratio, nitrogen retention and energy retention of 420 Nile tilapia fed different within-day mixed feeding schedules for 56 days.

\begin{tabular}{|c|c|c|c|}
\hline Treatments & RF am/RF pm & A am/B pm & B am/A pm \\
\hline Moisture\% & $76.7 \pm 0.7$ & $76.5 \pm 0.3$ & $76.9 \pm 0.4$ \\
\hline Crud protein\% & $12.3 \pm 0.3$ & $12.0 \pm 0.02$ & $11.8 \pm 0.1$ \\
\hline lipid \% & $7.2 \pm 0.4$ & $7.3 \pm 0.4$ & $7.8 \pm 0.7$ \\
\hline Ash\% & $3.6 \pm 0.4$ & $3.6 \pm 0.1$ & $3.4 \pm 0.3$ \\
\hline Gross energy (Kcal/100g) & $459.9 \pm 2.4$ & $460.0 \pm 0.7$ & $463.2 \pm 4.5$ \\
\hline
\end{tabular}

$\mathrm{SE} \pm$ standard errors calculated from residual mean square in the analysis of variance. Means in the same column with different superscription are significantly different $(P \leq 0.05)$

Table 5: Chemical body composition of the whole carcass of Nile tilapia fed different daily mixed feeding schedules for 56 days.

elevated trend in ER was observed with the increase of the feeding day's number $1 \mathrm{~A} / 1 \mathrm{~B}(12.5 \%), 2 \mathrm{~A} / 2 \mathrm{~B}(16.5 \%)$ and $3 \mathrm{~A} / 3 \mathrm{~B}(17.6 \%)$. Within the tested feeding schedules, $2 \mathrm{~A} / 2 \mathrm{~B}$ showed the best values and $1 \mathrm{~A} / 1 \mathrm{~B}$ had the lowest significant growth responses. Therefore, daily feeding schedules had no superior influence on fish performance, feed utilization, and body chemical composition compared to the control RF diet. In terms of body composition, no significant differences were noticed among daily feeding schedules in crude protein, lipid and ash contents (Table 3). However, fish fed 3A/3B feeding schedule showed the highest value of lipid and gross energy content, while, those of $1 \mathrm{~A} / 1 \mathrm{~B}$ recorded the lowest value. Meanwhile, moisture content showed the opposite trend to that of lipid content. In the second trial, growth performance and feed utilization are presented in Table 4 . The best value for growth responses, feed efficiency, and nutrients utilization were recorded for feeding schedule $(\mathrm{A}$ am/B pm) and $(\mathrm{RF}$ am/ $\mathrm{RF}$ pm) followed by (B am/A pm) ranking third with significant differences among treatments (Table $4, \mathrm{P} \leq 0.05$ ). In terms of body composition, no significant differences were observed among different treatments (Table 5).

\section{Discussion}

High growth rate and feed efficiency ratios were consistently observed throughout the two trials. The results of Trial \# 1 showed that there were significant differences in SGR, FER, NR or ER. Since the ingested feed intake was equal $(\sim 13 \mathrm{~g})$ among treatments, the low performance showed by $1 \mathrm{~A} / 1 \mathrm{~B}$ could be attributed to poor food utilization, not to a decrease in food intake. The first experiment concluded that RF feeding schedule recorded the highest values for most parameters. Within the tested feeding schedules, $2 \mathrm{~A} / 2 \mathrm{~B}$ showed the best values and $1 \mathrm{~A} / 1 \mathrm{~B}$ had the lowest significant growth responses. Therefore, daily feeding schedule had no superior influence on fish performance, feed utilization, and body chemical composition compared to the control RF diet. In contrast, previous studies reported a positive effect of daily feeding schedules on growth performance and feed efficiency compared to fish feed on continuous normal protein diets. In line with this pattern, Nile tilapia fed continuously high protein diet were less efficient in terms of growth and nutrient utilization compared to fish fed a high protein alternated with a low protein diet [9]. Moreover, earlier studies found that fish responded well to some of the feeding strategies (i.e., high-protein feed alternated with low-protein feed) as those fish achieved growth responses match or exceed the performance of fish reared entirely on the high-protein feed $[16,19,22]$. The discrepancy between the current and previous results 
Citation: Suloma A, El-Husseiny O, El-Haroun E, Salim H, Tahoun A (2017) Re-Evaluation of the Effect of Daily and Within-Day Mixed Feeding Schedules of Varying Dietary Protein Content on the Growth Performance of Nile Tilapia Fry Using Constant Ingredient Composition. $J$ Aquac Res Development S2: 009. doi:10.4172/2155-9546.S2-009

could be attributed to different contribution (\%) of the ingredients used in test diets formulation, and consequently, the unequal input of each ingredient in the chemical composition content like protein and energy occurred. In the current experimental design, this hypothesis is taken into consideration to achieve the similarity between feeding schedules treatments and regular feeding protocol to eliminate the impact of any variables other than mixed feeding schedules. In the second trial, the best value for growth responses, feed efficiency and nutrients utilization were recorded for feeding schedule ( $\mathrm{A} \mathrm{am} / \mathrm{B} \mathrm{pm})$ with ( $\mathrm{RF} \mathrm{am} / \mathrm{RF} \mathrm{pm})$ followed by (B am/A pm) ranking third with significant differences among treatments (Table $4, \mathrm{P} \leq 0.05$ ). The possible explanation of present results could be that the duration of $16 \mathrm{~h}$ between the afternoon meal and the next morning meal, in which tilapia was subjected to a certain level of fasting. Thus, delivering a low protein diet after this period of fasting may optimize the nutrient retention efficiency (FCR, PER, NR and ER) and thereby directing the fish to consume valuable protein in terms of growth and protein synthesis. These results are consistent with Gélineau et al. [30] who found that feeding trout at dawn may increase the channeling of amino acid into pathways for protein synthesis, or stimulate the hepatic activities of aminoacyl RNA synthesis, resulting in the reduction in the rate of amino acid catabolism and consequently enhance growth and nutrient utilization. Furthermore, Boujard et al. [29] found that channel catfish, showed less fat deposition when fed at dawn. Another perspective, high growth responses of fish fed $40 \%$ CP, then $30 \%$ CP and followed by fish fed $20 \%$ CP ranking third in the afternoon phase, indicated that tilapia utilize high protein diets during the afternoon phase more efficiently than that in the morning (Table 4). These results may be explained in various ways; firstly, the low activity level of fish during the afternoon phase allowed partitioning of food resources into somatic growth rather than as an underlying substrate for immediate activity $[39,40]$. Secondly, high digestion enzymes productivity, efficiency and stomach fullness of Nile tilapia occurred during the afternoon phases and consequently support nutrient partition toward growth [41]. Thirdly, feeding at certain times of the day was conducive to lean body growth and at other times to fattening [42]. Furthermore, El-Husseiny et al. $[43,44]$ reported that tilapia body metabolic system concentrated on the synthesis and deposition of fat when fish were delivered their diets in the morning, while in the afternoon, the body metabolic system focalized on synthesis protein. Nitrogen retention results showed lower values $(P \geq 0.05)$ at feeding schedule treatments compared to the $R F$ diet (Tables 4 and 5). The results are inconsistent with the findings of previous studies, De Silva [9]; De Silva and Anderson [45]; Nandeesha et al. [19,20]; Ali et al. [24]; El-husseiny et al. [46], El-Haroun et al. [47] who found that nitrogen waste output was decreased and consequently nitrogen retention increased by feeding schedules in Nile tilapia and carps. The lowest significant value of NR for the schedule $(40 \mathrm{am} / 20$ $\mathrm{pm}$ ) could be attributed to the low utilization of protein to meet energy requirements in the morning, after a long duration ( 16 hours) without feeding, resulting in an increase in amino acids catabolism, which increased the nitrogen load in the system [48].

\section{Conclusion}

Using a proper feeding schedule through alternate low-protein and high-protein within-day achieved better growth and feed utilization of Nile tilapia rather than alternate days. Thus, within-day mixed feeding schedules could be considered promising for tilapia. The results open up a new avenue in the development of more efficient feeding schedules using two separate diets within a single day. Further research is needed to develop this new strategy. Collaboration among fish nutritionists, farmer, and feed manufacturers are needed to put the within-day mixed feeding schedules into practice.

\section{References}

1. Sehgal $H$, Toor $H$ (1991) Comparison of feeding strategies for common carp based on biomass and biomass-pond interactions. Proceedings of the fourth Asian fish nutrition workshop. Asian Fish. Soc. Spec. Pub/. 5. Asian Fisheries Society, Manila, Philippines.

2. De Silva SS (1992) Fish nutrition research for semi-intensive culture systems in Asia. Asian Fisheries Science 5: 129-144.

3. Tahoun A, Suloma A, Hammouda Y, Abo-State H, El-Haroun E (2013) The effect of stocking different ratios of Nile tilapia Oreochromis niloticus, striped mullet mugil cephalus, and thinlip grey mullet liza ramada in polyculture ponds on biomass yield, feed efficiency, and production economics. North American Journal of Aquaculture 75: 548-555.

4. Hardy RW (1989) Practical feeding: Salmon and trout. Nutrition and feeding of fish. Van Nostrand Reinhold, New York.

5. Hardy RW (1996) Alternate protein sources for salmon and trout diets. Animal Feed Science Technology 59: 71-80.

6. Hertrampf JW, Piedad-Pascual F (2000) Handbook on ingredients for aquaculture feeds. Kluwer Academic Publishers, Dordrecht, The Netherlands.

7. Suloma A, Mabroke R, El-Haroun E (2013) Meat and bone meal as a potential source of phosphorus in plant-protein based diets for Nile tilapia (Oreochromis niloticus). Aquaculture International 21: 375-385.

8. Suloma A, El-Husseiny OM, Hassane MI, Mabroke RS, El-Haroun ER (2014) Complementary responses between hydrolyzed feather meal, fish meal and soybean meal without amino acid supplementation in Nile tilapia Oreochromis niloticus diets. Aquaculture International 22: 1377-1390.'

9. De Silva SS (1985) Performance of Oreochromis niloticus (L.) fry maintained on mixed feeding schedules of differing protein content. Aquaculture Fish Manage. 16: 331-340.

10. De Silva SS (1989) Reducing feed costs in semi-intensive aquaculture systems in the tropics. NAGA, ICLARM Quarterly 12: 6-7.

11. Suloma A, Ogata $H(2006)$ Future of rice-fish culture, desert aquaculture and feed development in Africa: the case of Egypt as the leading country in Africa. Japan Agricultural Research Quarterly JARQ 40: 351-360.|

12. Abo-Taleb M, El-Sherbiny M, Elnady M, Hassanien H, Suloma A, et al. (2014) Combined effects of periphyton substrate and alternate day feeding strategy on growth performance of Nile tilapia Oreochromis niloticus L. under green water tank culture. Egyptian. Journal of Aquaculture 4: 13-26.

13. De Silva SS, Perera MK (1983) Digestibility of an aquatic macrophyte by the cichlid Etroplus suratensis (Bloch) with observations on the relative merits of three indigenous components as markers and daily changes in protein digestibility. Journal of Fish Biology 23: 675-684.

14. De Silva SS, Perera MK (1984) Digestibility in Sarotherodon niloticus fry: Effect of dietary protein level and salinity with further observations on variability in daily digestibility. Aquacult Fish Manag 22: 397-403.

15. Santiago CB, Laron MA (2002) Growth and fry production of Nile tilapia Oreochromis niloticus (L.), on different feeding schedules. Aquaculture Research 33: 129-136.

16. Patel AB, Yakupitiyage A (2003) Mixed feeding schedules in semi-intensive pond culture of Nile tilapia, Oreochromis niloticus, L.: Is it necessary to have two diets of differing protein contents? Aquaculture Research 34: 1343-1352.

17. Bolivar RB, Jimenez EBT, Brown CL (2006) Alternate-day feeding strategy for Nile tilapia grow out in the Philippines: marginal cost-revenue analyses. North American Journal of Aquaculture 68: 192-197.

18. Srikanth GK, Nandeesha MC, Keshavanath P, Varghese TJ, Shetty HPC, et al. (1989) On the applicability of a mixed feeding schedule for common carp, Cyprinus carpio var. Communis. In Aquacultural Research in Asia: Management Techniques and Nutrition, Malang (Indonesia)

19. Nandeesha MC, De Silva SS, Krishnamurthy D, Dathatri K (1994) Use of mixed feeding schedules in fish culture. Aquacult Fisher Manag 25: 659-670.

20. Nandeesha MC, De Silva SS, Krishnamurthy D (1995) Use of mixed feeding schedules in fish culture performance of common carp, Cyprinus carpio L., on plant and animal protein based diets. Aquaculture Research 26: 161-166. 
Citation: Suloma A, El-Husseiny O, El-Haroun E, Salim H, Tahoun A (2017) Re-Evaluation of the Effect of Daily and Within-Day Mixed Feeding Schedules of Varying Dietary Protein Content on the Growth Performance of Nile Tilapia Fry Using Constant Ingredient Composition. $J$ Aquac Res Development S2: 009. doi:10.4172/2155-9546.S2-009

Page 5 of 5

21. Nandeesha MC, Gangadhara B, Manissery JK (2002) Further studies on the use of mixed feeding schedules with plant- and animal based diets for common carp Cyprinus carpio (L). Aquaculture Research 33: 1157-1162.

22. Nandeesha MC, Silva SS, De Krishna MD (1993) Evaluation of mixed feeding schedules in two Indian major carps, catla (Catla catla) and rohu (Labeo rohita). Fish nutrition in practice. INRA Editions, Paris, France.

23. Hashim R (1994) The effect of mixed feeding schedules of varying dietary crude protein content on the growth performance of Channa striata fry. Asian Fisher Sci7: 149-155.

24. Ali MZ, Hossain MA, Mazid MA (2005) Effect of mixed feeding schedules with varying dietary protein levels on the growth of sutchi catfish, Pangasius hypophthalmus (Sauvage) with silver carp, Hypophthalmichthys molitrix (Valenciennes) in ponds. Aquaculture Research 36: 627-634.

25. Fraser NHC, Metcalfe NB (1997) The cost of being nocturnal: feeding efficiency in relation to light intensity in juvenile Atlantic salmon. Functional Ecology 11 : 385-391.

26. López -Olmeda JF, Noble C, Sanchez-Vazquez FJ (2012) Does feeding time affect fish welfare? Fish Physiology and Biochemistry 38: 143-152.

27. Spieler RE, Noeske TA (1981) Timing of a single daily meal and diel variations of serum thyroxine, triiodothyronine and cortisol in goldfish Carassius auratus. Life Sci 28: 2939-2944.

28. Boujard T, Leatherland JF (1992) Circadian rhythms and feeding time in fishes. Environmental Biology of Fishes 35: 109-131.

29. Boujard T, Gélineau A, Corraze G (1995) Time of single daily meal influences growth performance in rainbow trout, Oncorhynchus mykiss. Aquac Res 26 341-349.

30. Gélineau A, Médale F, Boujard T (1998) Effect of feeding time on postprandia nitrogen excretion and energy expenditure in rainbow trout. Journal of Fish Biology 52: 655-664.

31. Madrid JA, Azzaydi M, Zamora S, Sánchez-Vázquez FJ (1997) Continuous recording of uneaten food pellets and demand-feeding activity -A new approach to studying feeding rhythms in fish", Physiology \& behavior 62: 689-695.

32. Chen WM, Purser J, Blyth $P$ (1999) Diel feeding rhythms of greenback flounder Rhombosolea tapirina (Günther 1862): The role of light-dark cycles and food deprivation. Aquaculture Research 30: 529-537.

33. Kerdchuen N, Legendre M (1991) Influence de la fréquence et de la période de nourrissage sur la croissance et l'efficacité alimentaire d'un silure africain, Heterobranchus longifilis (Teleostei, Clariidae). Aquatic Living Resources 4 241-248.

34. Jørgensen $\mathrm{EH}$, Jobling $\mathrm{M}$ (1992) Feeding behavior and effect of feeding regime on growth of Atlantic salmon, Salmo salar. Aquaculture 101: 135-146.

35. Houlihan D, Boujard H, Jobling M (2001) Food intake. Blackwell Science
Ltd. Bolliet V, Azzaydi M, Boujard, T. Effects of feeding time on feed intake and growth.

36. AOAC (Association of Official Analytical Chemists) (1990) Official methods of analysis of the Association of Official Analytical Chemists. Thirteenth edition. Association of Official Analytical Chemists (publisher), Washington, DC 20044, USA

37. Young A, Morris P, Huntingford F, Sinnott R (2005) The effects of diet, feeding regime and catch-up growth on flesh quality attributes of large (1+ sea winter) Atlantic salmon, Salmo salar. Aquaculture 248: 59-73.

38. SAS Institute (1988) SAS/STAT User's Guide, Release 6.03 ed. SAS Institute, Cary, North Carolina.

39. Baras E, Melard C, Thoureau X (1995) Influence of feeding time on growth and feed conversion rates in juvenile tilapia (Oreochromis niloticus). Cahiers D'ethologie Fondamentale Et Appliquee, Animale Et Humaine, Liège 15: 71-80.

40. Heilman MJ, Spieler RE (1999) The daily feeding rhythm to demand feeders and the effects of timed meal-feeding on the growth of juvenile Florida pompano, Trachinotus carolinus. Aquaculture 180: 53-64

41. Getachew T (1989) Stomach $\mathrm{pH}$, feeding rhythm and ingestion rate in Oreochromis niloticus L. (Pisces: Cichlidae) in Lake Awasa, Ethiopia, Hydrobiologia 174: 43-48.

42. Noeske-Hallin, TA, Spieler RE, Parker NC, Suttle AA (1985) Feeding time differentially affects fattening and growth of channel catfish. J Nutr 115 :1228-1232.

43. El- Husseiny OM, Abdul -Aziz GEM, El Samei AM, Mabroke RS (2002) Influence of diet composition and feeding regime on Nile tilapia (Oreochromis niloticus) performance. M.Sc thesis. Animal Production Department, Faculty of Agriculture, Cairo University

44. El-Husseiny OM, Abdul-Aziz GM, Goda AMS, Suloma A (2010) Effect of altering linoleic acid and linolenic acid dietary levels and ratios on the performance and tissue fatty acid profiles of Nile tilapia Oreochromis niloticus fry. Aquaculture international 18: 1105-1119.

45. De Silva SS, Anderson TA (1995) Fish nutrition in aquaculture. London Chapman \& Hall.

46. El-Husseiny OM, Goda AM, Hassan I, Suloma A (2013) Modelling digestibility coefficients of plant protein sources and levels in tilapia diets.' Journal of the Arabian aquaculture society 3: 455-468.

47. El-Haroun ER, Suloma A, Mabroke RS, Salim H, Kumar V (2016) Tryptophan supplementation of meat and bone meal in lysine-enriched diets improves growth performance and nutrient utilization by Nile Tilapia, Oreochromis niloticus. J Aquac Res Development 7: 439.

48. Lloyd LE, McDonald BE, Crampton EW (1978) Feeding time differentially affects fattening and growth of channel catfish. J Nutr 115: 1228-1232.
This article was originally published in a special issue, Current and Emerging Diseases/Disorders of Fish in Aquaculture handled by Editor(s). Prof. Patrick T.K. Woo, University of Guelph, Canada; Dr. Kenneth D. Cain, University of Idaho, USA. 